\title{
Variability of Environmental Quality and Dynamics of Malaria in Sarmi District
}

\section{Mark Leynard Julianus Tetelepta ${ }^{1}$, Mursid Raharjo ${ }^{2}$, Nurjazuli ${ }^{3}$}

\author{
${ }^{1}$ Student of Master of Environmental Health, Public Health Faculty, Diponegoro University, Indonesia \\ Email: marktetelepta2@gmail.com \\ ${ }^{2,3}$ Lecturer of Master of Environmental Health, Public Health Faculty, Diponegoro University, Indonesia
}

\begin{abstract}
Malaria is an infectious disease that is of global concern. This disease is still a public health problem because it often causes outbreaks. Sarmi Regency specifically in Betaf Health Center working area API number 642 per 100 population, Sarmi Regency ranks fourth with API number 16,250 per 1000 population in Papua province in 2018. This study aimed to analyze the variability of environmental quality and malaria dynamics in the Puskesmas Work Area Betaf East Coast District, Sarmi Regency. This study used a case control design. The research sample of 124 respondents, consisting of 62 cases and 62 controls were randomly drawn. The variables studied were environmental factors (temperature, humidity, water $\mathrm{pH}$, the presence of cattle pens, the presence of resting places, and the presence of breeding places), behavioral factors (the habit of being outside at night, the use of anti-mosquito repellent, the use of mosquito nets, and the use of wire mesh on ventilation), mosquito density, type of mosquito, and the incidence of malaria. Data analysis used chi square and logistic regression. Malaria API of Sarmi Regency in the period 2014 - 2018 showed a significant increase in the number of cases and API in 2018. The results of the study showed that the variables proven as risk factors for malaria were air temperature $(O R=3,66595 \% C I=1,728-7,776)$, humidity $(O R=5,03795 \% C I=1,742$ 14,564), habits outside the home (OR 5,043 95\% CI =1,578-16,120), habits using mosquito nets $(O R=4,242$ $95 \% C I=1,212-16,046)$. The most influential variable on the incidence of malaria is environmental variability in air temperature $(p=0.00395 \% C I=0.137$ - 0.661). The probability of suffering from malaria in respondents living at 25-27oC is 79\%. The air temperature affects the breeding of Anopheles sp. Mosquitoes, where the mosquitoes can develop optimally at a temperature of 25-27oC.
\end{abstract}

Keywords-malaria, environmental factors, behavioral factors, spatial, Sarmi Regency.

\section{INTRODUCTION}

Malaria is a disease that is a threat to the community in the tropics and sub-tropics, especially in infants, toddlers and mothers giving birth. Around the world every year 500 million cases of malaria are found, resulting in 1 million deaths. ${ }^{1}$. Changes in the weather triggers an increase in Anopheles species which are vectors of malaria transmission ${ }^{2}$. Based on data from the World Health Organization (WHO) in the World Malaria Report in 2015 there were reported 214 million new cases of malaria and an estimated 438,000 malaria deaths (range 236000 - 635000) worldwide. Most of these regions occur in Africa (90\%), followed by Southeast Asia (7\%) and East Regional Mediaterania $(2 \%){ }^{3}$ If seen from the national (annual parasite incidance) API trend of malaria in Indonesia in 2009-2017, the number of positive malaria cases per 1000 population in 2009 API (annual parasite incidance) 1.8 in 2010 API (annual parasite incidance) 1.96 years 2011 API (annual parasite incidance) 1.75 in 2012 API (annual parasite incidance) 1.69 in 2013 API (annual parasite incidance) 1.38 in 2014 API (annual parasite incidance) 0.99 and in 2015 API (annual parasite incidance) 0.85. Papua Province is the Province with the highest API (annual parasite incidance), which is 59.00 per 1,000 population. This figure is very high when compared to other provinces. The three provinces with the highest API per 1,000 population, namely West Papua (14.97), East Nusa Tenggara (5.76), and Maluku (2.30). As many as $90 \%$ of cases came from Papua, West Papua and East Nusa Tenggara. ${ }^{4}$

The situation of malaria in Papua Province in 2017 can be seen from the health profile of Papua Province API number (annual parasite incidence) or the number of malaria sufferers per 1000 population in 2011 that is API 58 per 1000 population, in 2012 API 77, in 2013 API 50, however in 2015 the number of APIs rose to 54.24 and in 2017 the number of APIs fell to 52.32.5 Sarmi Regency has 11 Puskesmas, namely, Burtin, Betaf, Bonggo, East Bonggo, Samanente, Sarmi, Bagaiserwar, Petam, Arbais, West Bonggo, and Aurimi Puskesmas. Based on data, the 
highest API Puskesmas is in Betaf Puskesmas (API 642 per 1000 population), followed by East Bonggo Puskesmas (API 372 per 1000 population), and West Bonggo Puskesmas (API 322 per 1000 Population). 6 Some identification problems, related to the prevalence of malaria in Sarmi Regency, are a number of malaria eradication programs that have been implemented, such as treatment, spraying, abatesation, distribution of mosquito nets and counseling, but the incidence of malaria cannot be reduced or minimized. Characteristics of the environment with the development of malaria vectors where generally the Sarmi area is low level, the slope is $0-7 \%$, the coastal swamp is swamped with water. Tidal height of 5-7 meters, rainfall an average of 3,000 millimeters to 5,000 millimeters / year with rainy days around 230 days a year. The humidity level is quite high because it is influenced by the wet tropical climate, the average humidity ranges from $75 \%$ to $80 \%$. This study aims to determine the variability of environmental quality and dynamics of malaria that influence the incidence of malaria in the Betaf Health Center Work Area, East Coast District, Sarmi Regency.

\section{METHODS}

The research was carried out in the working area of Betaf Public Health Center, East Coast District, Sarmi Regency. This study used a case control design. The minimum sample size calculated based on the case control formula (1).

$$
n_{1}=n_{2}=\frac{\left(z a \sqrt{(2 P Q}+z_{\beta} \sqrt{P_{1} Q_{1}+P_{2} Q_{2}}\right)^{2}}{\left(P_{1}-P_{2}\right)^{2}} \ldots
$$

Information :

$\mathrm{Za}=$ Type one error $5 \%=1.96$

$\mathrm{Z}_{\beta}=$ Type two error $=0,842$

$\mathrm{P} 1=$ Proportion of cases $=3,434$

$\mathrm{P} 2=$ Proportion of effects on controls $=0.587$

$\mathrm{OR}=$ Odds Ratio based on previous risk factors

Table 1. Odd Ratio (OR) of several studies that have been conducted

\begin{tabular}{|c|c|c|c|}
\hline No & Variable & OR & $\begin{array}{l}\text { Researcher } \\
\text { and Year }\end{array}$ \\
\hline 1 & $\begin{array}{l}\text { The use of mosquito } \\
\text { nets }\end{array}$ & 5,182 & $\begin{array}{c}\text { Yawan / } \\
2006\end{array}$ \\
\hline 2 & $\begin{array}{l}\text { The habit of using } \\
\text { mosquito repellent }\end{array}$ & 3,343 & Hasrah/ 2015 \\
\hline 3 & $\begin{array}{l}\text { The existence of } \\
\text { standing water } \\
\text { (breeding place) }\end{array}$ & 4,250 & $\begin{array}{l}\text { Saputro / } \\
2015\end{array}$ \\
\hline 4 & $\begin{array}{l}\text { The presence of cattle } \\
\text { pens }\end{array}$ & 4,343 & $\begin{array}{l}\text { Saputro / } \\
2015\end{array}$ \\
\hline
\end{tabular}

Based on previous research entitled "Analysis of Malaria Incidence Risk Factors in Kuala Bhee Community Health Center in Woyla District, West Aceh Regency in 2015" by Hasrah Junaidi, with an OR value of 3.343 with an estimated proportion of the comparison group 0.5 . The calculation results showed that the minimum sample size of 56. To overcome the drop out then add $10 \%$ to 62 samples. Total samples for cases and controls were 124 samples. Case criteria were respondents who were affected by malaria and had a positive laboratory/microscopic examination and controls were respondents who had never had malaria.

The independent variables in this study are the presence of breeding places, the existence of resting places, the presence of livestock pens, the habit of being outdoors at night, the use of mosquito nets, the use of anti-mosquito repellent, the use of wire netting in ventilation, temperature, humidity, and water $\mathrm{pH}$. The analytical method used consists of univariate analysis, bivariate analysis with chi-square test to obtain an OR value of the independent variables and multivariate analysis to determine the risk of the independent variable on malaria incidence by considering other risk factors together with logistic regression.

\section{RESULTS}

Data obtained from the malaria case report at the Betaf Public Health Center - East Coast District, Sarmi Regency in the period of 2014 - 2018 showed a significant increase in the number of cases and APIs in 2018. API reached 642 per 1000 population increased significantly compared to previous years (Fig.1).

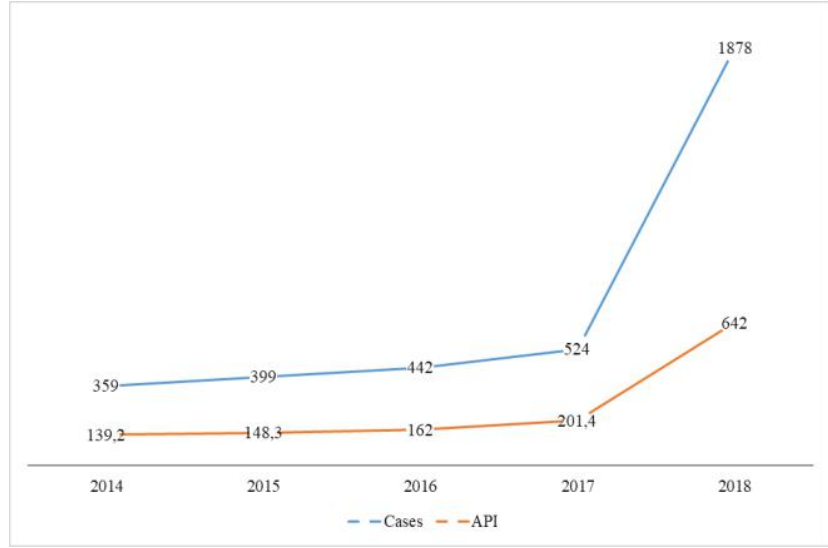

Fig.1: Malaria Cases in the Last 5 Years

The analysis showed that based on age group, there were 61 respondents $(49.2 \%)$ in the young age group (12 - 35 years old) and 63 respondents $(50.8 \%)$ were in the old age group (36-65 years). Based on the sex of male respondents as many as 55 (44.4) while those who become female respondents amounted to $69(55.6 \%)$. Based on the education level of respondents who did not complete 
elementary school numbered 9 (7.3)\%, elementary school 46 respondents (37.1), junior high school 34 respondents (27.4), high school 27 respondents (21.8) and tertiary institutions 8 respondents $(6,5 \%)$. Based on the work of respondents who work as PNS / POLRI / TNI 8 respondents $(6.5 \%)$, farmers 32 respondents $(25.8 \%)$, private 14 respondents $(11.3 \%)$, fishermen 2 respondents $(1.6 \%)$, students 17 respondents $(13.7 \%)$ and 51 respondents $(41.1 \%)$ not working.

The results of identification of the types of mosquito breeding sites obtained information of coconut shells, used tires, trenches, used jerry cans, used ponds and used cans are mosquito breeding sites in the study area. Used jerry cans and used tires are mosquito breeding places that are quite close to the respondent's house. While the pond is a breeding place for mosquitoes whose existence is quite far (more than $20 \mathrm{~m}$ ) from the respondent's houses. At the time of field observation, many anopheles larvae were found in the breeding sites. The results of environmental observations of the mosquito resting area showed that the mosquito resting sites in the study site included: ornamental plants, thatch trees, bamboo trees, bushes. Observations on the resting places also show the presence of mosquitoes that rest in these places, although only a little relatively. Catching adult mosquitoes (with aspirators) is carried out at these resting places.

The results of identification by the Research and Development Center for Disease Vectors and Reservoirs (B2P2VRP) Salatiga showed that of the 130 mosquitoes examined there were 97 of them, Anopheles mosquito, 6 aedes sp. And 14 culex quinquefasciatus. Among the 97 identified anopheles, there were 64 anopheles farauti, 15 anopheles punctulatus and 12 anopheles koliensis. Environmental conditions related to the development of malaria vector mosquitoes in an area consist of temperature, humidity, and water $\mathrm{pH}$. Based on the results of measurements in the field, the average environmental conditions are known as in the following table 2 .

Table 2. Environmental Conditions

\begin{tabular}{llll}
\hline $\begin{array}{l}\text { Environmental } \\
\text { conditions }\end{array}$ & Mean & $\begin{array}{l}\text { Minimu } \\
\mathrm{m}\end{array}$ & Maksimum \\
\hline Temperature & 27,2 & 26,2 & 29,5 \\
Humidity & 73,0 & 58,0 & 87,0 \\
water pH & 7,4 & 6,5 & 8,7 \\
\hline
\end{tabular}

Table 3. Risk factor analysis

\begin{tabular}{|c|c|c|c|c|c|c|c|c|}
\hline \multirow{3}{*}{ Risk factors } & \multicolumn{4}{|c|}{ Malaria incident } & \multirow{2}{*}{\multicolumn{2}{|c|}{ Total }} & \multirow{3}{*}{$P$ value } & \multirow{3}{*}{ OR $(95 \% \mathrm{CI})$} \\
\hline & \multicolumn{2}{|c|}{ Control } & \multicolumn{2}{|c|}{ Case } & & & & \\
\hline & $\mathrm{n}$ & $\%$ & $\mathrm{n}$ & $\%$ & $\mathrm{n}$ & $\%$ & & \\
\hline \multicolumn{9}{|l|}{ Temperature } \\
\hline Potential & 45 & 72,6 & 26 & 41,9 & 71 & 57,3 & 0,001 & 3,665 \\
\hline No potential & 17 & 27,4 & 36 & 26,5 & 53 & 42,7 & & $(1,728-7,776)$ \\
\hline
\end{tabular}




\begin{tabular}{|c|c|c|c|c|c|c|c|c|}
\hline \multicolumn{9}{|l|}{ Humidity } \\
\hline Potential & 57 & 91,9 & 43 & 69,4 & 100 & 80,6 & \multirow[t]{2}{*}{0,003} & \multirow[t]{2}{*}{$\begin{array}{c}5,037 \\
(1,742-14,56)\end{array}$} \\
\hline No potential & 5 & 8,1 & 19 & 30,6 & 24 & 19,4 & & \\
\hline \multicolumn{9}{|l|}{ Water $\mathrm{pH}$} \\
\hline Potential & 44 & 71,0 & 53 & 85,5 & 97 & 78,2 & \multirow[t]{2}{*}{0,82} & 0,415 \\
\hline No potential & 18 & 29,0 & 9 & 14,5 & 27 & 21,8 & & $(0,170-1,051)$ \\
\hline \multicolumn{9}{|l|}{ Cattle pen } \\
\hline There is & 8 & 12,9 & 3 & 4,8 & 11 & 8,9 & \multirow[t]{2}{*}{0,206} & 2,914 \\
\hline There is no & 54 & 87,1 & 59 & 95,2 & 113 & 91,1 & & $(0,735-11,55)$ \\
\hline \multicolumn{9}{|c|}{ The existence of resting place } \\
\hline There is & 47 & 75,8 & 40 & 64,5 & 87 & 70,2 & \multirow[t]{2}{*}{0,239} & 1,723 \\
\hline There is no & 15 & 24,2 & 22 & 35,5 & 37 & 29,8 & & $(0,790-3,760)$ \\
\hline \multicolumn{9}{|c|}{$\begin{array}{l}\text { The existence of breeding } \\
\text { place }\end{array}$} \\
\hline There is & 31 & 50,0 & 32 & 51,6 & 63 & 50,8 & \multirow[t]{2}{*}{1,000} & 0,938 \\
\hline There is no & 31 & 50,0 & 30 & 48,4 & 61 & 49,2 & & $(0,464-1,896)$ \\
\hline \multicolumn{9}{|c|}{ The habit of being outdoors } \\
\hline Yes & 58 & 93,5 & 46 & 74,2 & 104 & 83,9 & \multirow[t]{2}{*}{0,007} & 5,043 \\
\hline No & 4 & 6,5 & 16 & 25,8 & 20 & 16.1 & & $(1,578-16,12)$ \\
\hline \multicolumn{9}{|c|}{$\begin{array}{l}\text { Habit of using mosquito } \\
\text { repellent }\end{array}$} \\
\hline Yes & 18 & 29,0 & 12 & 19,4 & 30 & 24,2 & \multirow[t]{2}{*}{0,294} & 1,705 \\
\hline No & 44 & 71,0 & 50 & 80,6 & 94 & 75,8 & & $(0,739-3,930)$ \\
\hline \multicolumn{9}{|c|}{ Habit of using mosquito nets } \\
\hline Yes & 59 & 95,2 & 51 & 82,3 & 110 & 88,7 & \multirow[t]{2}{*}{0,047} & 4,242 \\
\hline No & 3 & 4,8 & 11 & 17,7 & 14 & 11,3 & & $(1,212-16,04)$ \\
\hline \multicolumn{9}{|c|}{ The habit of using wire } \\
\hline Yes & 21 & 33,9 & 20 & 32,3 & 41 & 33,1 & \multirow[t]{2}{*}{1,000} & $1,076-$ \\
\hline No & 41 & 66,1 & 42 & 67,7 & 83 & 66,9 & & $(0,509-2,274)$ \\
\hline
\end{tabular}

Multivariate analysis was performed to see the most dominant risk factor causing a health problem. In this study, a multivariate analysis was conducted to look at the most dominant risk factors causing malaria in the work area of the Betaf Health Center. The results of multivariate analysis showed that the air temperature variable was the most dominant risk factor for the incidence of malaria (sig
0.003) (Table 4). Based on the calculation of probability or (risk) predictions of individuals who can experience malaria, it is known that the respondent's air temperature of $25-27^{\circ} \mathrm{C}$ has a probability (probability) of suffering from malaria by $79 \%$.

Table 4. Logistic regression test results

\begin{tabular}{clccccc}
\hline No & \multicolumn{1}{c}{ Variable } & B & Wald & Sig & Exp(B) & $95 \%$ CI \\
\hline \multirow{2}{*}{1} & The habit of being & 1,082 & 2,664 & 0,103 & 2,951 & $0,805-$ \\
& outdoors & 1,201 & 8,951 & 0,003 & 3,323 & $1,513-7,297$ \\
2 & Temperature & 1,092 & 3,256 & 0,071 & 2,979 & $0,910-9,749$ \\
3 & Humidity & $-2,523$ & 12,955 & 0,000 & 0,910 & \\
& constant & & & & \\
\hline
\end{tabular}

\section{DISCUSSION}

Based on bivariate analysis showed that there is a significant relationship between air temperature and the incidence of malaria ( $\mathrm{p}$-value $=0.001$ ) and the value of OR $=3.665$. The results of this study prove that temperature is one of the factors that influence the incidence of malaria. This research is also in line with research conducted in China's Yunan province which states that malaria transmission is influenced by climate, namely temperature.
At warmer temperatures will affect malaria transmission as happened in Jinhong. An increase in temperature results in a period of mosquito development and an increase in mosquito behavior in biting will thus result in transmission of malaria. ${ }^{7}$ Statistical test results show that widening humidity contributes greatly to an increase in malaria incidence due to the coolness felt by Anopheles sp. Moisture suitability intended for Anopheles sp. triggers an increased incidence of malaria. Obtained p-velue value of 
0.001 and OR value $=5.037$ means that respondents who have optimal humidity will be at risk of malaria being 5.037 times greater than respondents who have nonoptimal humidity, meaning that humidity is related to the incidence of malaria in the work area of the Betaf Public Health Center. The average humidity at the study site was $73.0 \%$, indicating that the humidity at the study site was optimal humidity. This research is the same as the research conducted in the village of Durian Lucuk, that humidity is associated with the incidence of malaria with a $\mathrm{p}$ value $=$ $0.006^{8}$

The results showed that the average humidity in Sarmi District was above $60 \%$. Chi-square statistical test results obtained $\mathrm{p}$ value $=0.007$ with $\mathrm{OR}=5.043$ and $95 \%$ $\mathrm{CI}=1.578-16.120$ which means there is a significant relationship between the habits of respondents outside the house at night with the incidence of malaria. The OR value of> 1 and the lower upper value of $95 \%$ CI of more than 1 means that respondents who have the habit of being outside at night are 5,043 times more likely to get malaria than those who do not have the habit of going out at night. This study is also not in line with research conducted by Hasyim in Lahat district regarding the determinants of malaria incidence in endemic areas stating that there is a significant relationship between the habits of going out at night with the incidence of malaria. ${ }^{9}$

However, this study is in line with research conducted by Rangkuti on environmental and behavioral factors relating to the incidence of malaria in the District of Panyabungan Mandailing Natal, North Sumatra. 01 with an OR value of 3.254 and $95 \% \mathrm{CI}=1.563-6.7777$. With an OR value of more than 1 , which means people with the habit of going out at night are 3.254 times more likely to get malaria than those who don't have the habit of going out at night. ${ }^{10}$

Based on the results of bivariate analysis showed that the habit of using mosquito nets has a significant relationship to the incidence of malaria obtained $\mathrm{p}$ value $=$ 0.047 with an $\mathrm{OR}$ value $=4.242$ and a value of $95 \% \mathrm{CI}=$ 1.121 - 16.046 this means that an OR value of more than 1 indicates that people who sleep do not use mosquito nets will be 4,242 times more likely to get malaria compared to people who sleep using mosquito nets. The habit of using mosquito nets is an effective effort to prevent and avoid contact between anopheles spp mosquitoes and healthy people during sleepless nights. Because the habit of anophles mosquitoes looking for blood is at night, thus always sleeping using a mosquito net that is not damaged or perforated at night can prevent or protect from the bite of anopheles spp. ${ }^{11}$

One effort can be made to control malaria vectors using Nanoparticles from Silver Nitrate $\left(\mathrm{Ag}_{2} \mathrm{NO}_{3}\right)$ and Carbamate $\left(\mathrm{CO}_{2} \mathrm{NH}_{3}\right.$ derivatives $)$. As research conducted by Raharjo et al (2019) showed that nanosilver proven effective as a vector insecticide. ${ }^{12}$

\section{CONCLUSION}

Sarmi Regency as a malaria endemic area needs to be studied regarding the factors that influence malaria in this region. Significantly related and proven variables as risk factors for malaria are air temperature $(\mathrm{OR}=3,665$ $95 \% \mathrm{CI}=1,728-7,776)$, humidity $(\mathrm{OR}=5,03795 \% \mathrm{CI}=$ 1,742-14,564), habits outside the home (OR 5,043 95\% CI $=1,578-16,120)$, habit of using mosquito nets $(\mathrm{OR}=4,242$ $95 \% \mathrm{CI}=1,212-16,046)$. The most influential variable on the incidence of malaria is environmental variability in air temperature $(\mathrm{p}=0.00395 \% \mathrm{CI}=0.137-0.661)$. The probability of suffering from malaria in respondents living at $25-27^{\circ} \mathrm{C}$ was $79 \%$.

\section{REFERENCES}

[1] Romi T, Putra I. Malaria dan Permasalahannya. 2011;11:103-14.

[2] Raharjo M, Yusniar H, Praba G. The New Spesies Anopheles aitkeni as the Threat of Malaria in Indonesia. Indian Journal of Public Health Research \& Development. 2018;9(4):206.

[3] WHO. world malaria report. In 2015.

[4] Kementrian Kesehatan. Profil Kesehatan Indonesia. jakarta: Kementrian Kesehatan; 2017.

[5] Dinas Kesehatan Provinsi Papua. Profil Kesehatan Provinsi Papua. 2017.

[6] Dinas Kesehatan Kabupaten Sarmi. Profil Kesehatan Kabupaten Sarmi. 2018;

[7] Wardrop NA, Barnett AG, Atkinson JA, Clements AC. Plasmodium vivax malaria incidence over time and its association with temperature and rainfall in four counties of Yunnan Province, China. malaria journal. 2013;12(1):111.

[8] Rachman I, Harahap PS, Alanuari A, Suhermanto S. Suhu, Kelembaban Dan Penggunaan Kelambu Berkaitan Dengan Tingginya Kejadian Malaria Di Desa Durian Luncuk. (Endurance jurnal). 2017;2(2):194.

[9] Hasyim H, Camelia A, Alam NF. Determinan Kejadian Malaria di Wilayah Endemis. Kesehatan Masyarakat Nasional. 2014;8(7):291-4.

[10] Rangkuti AF, Sulistyani S, Endah W N. Faktor Lingkungan dan Perilaku yang Berhubungan dengan Kejadian Malaria di Kecamatan Panyabungan Mandailing Natal Sumatera Utara. Balaba: Jurnal Litbang Pengendalian Penyakit Bersumber Binatang Banjarnegara. 2017;13(1):1-10.

[11] Umar F. Manajemen Penyakit Berbasis Wilayah. UI Press. Jakarta.; 2008.

[12] Raharjo M, Subagyo A, Sulistyani S. Nanoparticle of Silver Nitrate (Ag2NO3) and Carbamate (CO2NH3 derivatives) For Vector Control of Aedes aegypti. E3S W eb of Conferences 1. 2019;125. 